\title{
Waxing Effect on the Physical Attributes, Antioxidant and Sugar Contents of Orange (Citrus sinensis L. osbeek) Stored at Room Temperature in Nigeria
}

\author{
Adetuyi, F. O* Ibrahim, T. A; Ajalia Lola and Oloye D.A
}

Food Science and Technology Department, Rufus Giwa Polytechnic P.M.B 1019, Owo, Ondo State, Nigeria.

\begin{abstract}
The objective of this work was to determine the influence of edible wax and non-edible wax on the physical attributes, vitamin $\mathrm{C}$ and total phenol of orange stored at room temperature $\left(28 \pm 5^{\circ} \mathrm{C}\right)$ in Nigeria. The oranges were divided into three lots, viz one was waxed with sheabutter, the second with petroleum wax and the third was left unwaxed. They were subsequently analyzed for physical apperance, weight loss, vitamin $\mathrm{C}$ and total phenol. The waxed orange had a better appearance and market appeal than the unwaxed orange. The percentage weight loss in unwaxed orange 5.88\% was higher than significantly (P0.05) higher in waxed than the unwaxed orange at every sampling point while there was no significant (P0.05) difference in the total phenol of both waxed and unwaxed orange. It is concluded that oranges should be waxed with sheabutter because it had better qualities than unwaxed and pertoleum waxed orange and also to prevent postharvest losses in these orange.
\end{abstract}

Key words: Waxed, Unwaxed, Orange, Vitamin C, Phenol

\section{Introduction}

Epidemiological evidence relates fruit consumption to the risk of degenerative diseases. In this sense the antioxidant properties of many fruit and vegetables are widely recognized (Biolatto et al 2005). Natural antioxidants found in these products include phenolics and nitrogen compound, carotenoids and some vitamins; vitamin C plays several roles in human health (Harris 1996). The requirements of vitamin $\mathrm{C}$ are $90 \mathrm{mg} /$ day for young women and $75 \mathrm{mg}$ day for men (Levine et al 2001). More than $90 \%$ of vitamin C in human diets is supplied by fruits and vegetable (Wills et al 1984). Citrus fruit is the most important source of vitamin C because of the large quantities consumed (Biolatto et al 2005). The sweet orange Citrus sinensis L. Osbeck are very tasty and nutritious, containing $5-10 \%$ sugar, $1-2 \%$ citric acid, along with vitamin $\mathrm{C}$ and beneficial fibre and pulp. Most sweet orange have an orange coloured rind when they are ripe as well as an orange interior and juice. Oranges are grown in enormous quantities and are readily available as an inexpensive fruit at anytime of the year (Arthey and Ashurst, 1996). Orange fruit are the most popular ones for consumer throughout the world due to their pleasant flovours and nutritional value (Dhuique-Mayer et al 2005). The fruits are both consumed fresh and industrially processed. Orange peels contain abundant fragment substances which are extensively applied for processing into essential oils which are used

\footnotetext{
* Corresponding author: E-mail: foluadetuyi@yahoo.co.uk
}

commercially for flavorign foods, veberages, perfumes, cosmetics (Dhuique-Meyer et al 2005). In Nigeria, enormous quantities of fruits and vegetables are produced and staggering figures are sometimes given as estimated annual producation. for example, figures like 15 million tones of plantain, 6 million tones of tomatoes and 35 million of tones of citrus have been quoted as annual production levels for some fruits and vegetables, which are really large quantities of food crops (Oyedrian, 1988, Erinle, 1989). However, it is the amount of the produce available to the consumers rather than the level of production that is more important (Idah et al 2007). It is noted that losses as high as $50 \%$ are common in fruits and vegetables between rural porduction and town consumption in the tropics (Oyedrian 1988). It is noted that these losses, occured during transportation, storage and marketing (Daramola 1998, Okhuoya 1995). In Nigeria oranges (Citrus sinensis L Osbeck) are produced in the south western state and transported to other parts of the country where the consumption is highest and where the orange command better prices. The oranges in Nigeria are packed into an open truck and transported during which they are exposed to high ambient temperature which will result into shriveling due to weight loss and the appearence will be poor. The poor appearance reduces market appeal and contributes to post harvest losses in orange fruit under tropical condition 
(Aworh et al 1991). In developed countries mechanical refrigeration, controlled atmospheres, hypobaric storage and other techniques are used to extend storage life (Aworh et al 1991) and during transportation of these citrus fruits. In Nigeria, due to poor road network from the outlying villages to the markets (Adetuyi et al, 2008a) on the average produce normally spends four to five days in transit, out of which two days are spent on movement from the production site to the market and the remaining days spent at source markets (Idah et al, 2007). To our knowledge most of the data on the nutritional status of orange in Nigeria focused on the proximate, mineral and how to prevent microbial spoilage of orange with little information on the effect of postharvest treatement on the nutriotional constituents of orange. The present study was designed to examine the effect of postharvest treatment of waxing orange with edible (shea butter) and non-edible (petroleum wax) wax on the physical attributes, phenol, vitamin $\mathrm{C}$ and sugar content of stored orange.

\section{Materials and Methods}

Freshly harvested oranges Citrus sinensis used for this suudy were yellow with green patches; they were purchased from an orange farm in 'Ago paanu' village in Owo Local Government area of Ondo State. The shea butter and the petroleum wax were purchased form 'Oja Oba' in Akure Ondo State. The chemicals used in this work were of analytical grade.

\section{Sample preparation}

The oranges were washed and mixed randomly, thirty (30) orange fruits which were free from physical damage, insect infestation and blemishes were selected and divided into three lots, one lot was waxed with peroleum was, the second one was waxed with shea butter while the third one was left untereated. All the three lots were separately stored in polypropylene bag container at room temperature $\left(28+5^{\circ} \mathrm{C}\right)$ for 120 hours. The treatments were replicated twice. Fruit was analyzed immediately on arrival in the laboratory and after treatment using the unreated sample as the control. Fruits were analyzed every 24 hours for the follwoing characteristics (1) external appearance (2) weight loss (3) Vitamin C (4) Total phenol (5) juice total sugar and glucose.

\section{Weight loss and appearance}

Weight loss was determined by weighing the fruit in each treatment at 24 hours intervals during the storage period and is expressed as a percentage of the initial weight (Aworh et al., 1991). The appearance of the fruit was visually determined and is expressed as percentage of fruit surface shriveled (Matta et al., 2006).

\section{Sample analysis}

The Vitamin C of the orange juice was determined by the iodine titration method as described by Suntornsuk et al (2002). The total phenol was determined using the FolinCiocalteu's reagent as described by Lim et al (2006), and reported as gallic acid equivalent (GAE). Total sugar and glucose, were identified and quantified according to the method of Albuquerque et al (2005) by HPLC using a waters R401refractive index detector and a sugar-pack water column.

\section{Statistical analysis}

Analysis of variance (ANOVA) was performed on the results of each quality variable to determine the signuificance of the effecrts of waxing on the fruits quality Means were compared by the least signnificance difference LSD test. Significance was set at $\mathrm{P}<\_0.05$.

\section{Results and Discussion}

The weight loss in both the waxed and unwaxed oranges is presented in figure 1 . The percentage weight loss in unwaxed orange (5.88\%) was higher then the waxed orange at the end of the storage period. There was no difference in the percentage weight loss of shea butter waxed and petroleum waxed orange, they recorded the least percentage weight loss of $3.18 \%$ and $3.06 \%$ respectively, and this agreed with the report of Aworh et al. (1991) that waxing minimized weight loss in orange and grapefruit during storage at ambient conditions. This could be attributed to the inhibition of moisture loss from the rind of citru fruit by the wax material (Aworh et al 1991). The percentage of orange with shriveled surfaces was significantly low in waxed orange than unwaxed orange which means that waxed orange had a better appearance and market appeal than the unwaxed orange (Figure 2). This finding agreed with the earlier observation of Aworh et al (1991) that orange and grape waxed had a better appearance than the unwaxed fruit. This was attributed to the reduction of moisture loss from the fruit caused by the waxing agent on the fruit, thus minimizing shriveling and contributing to the better appearance of waxed fruit (Aworh et al 1991). Gomez (2000) also observed that the use of wax on passion fruit extend the shelf life of the product, reduced weight losses 


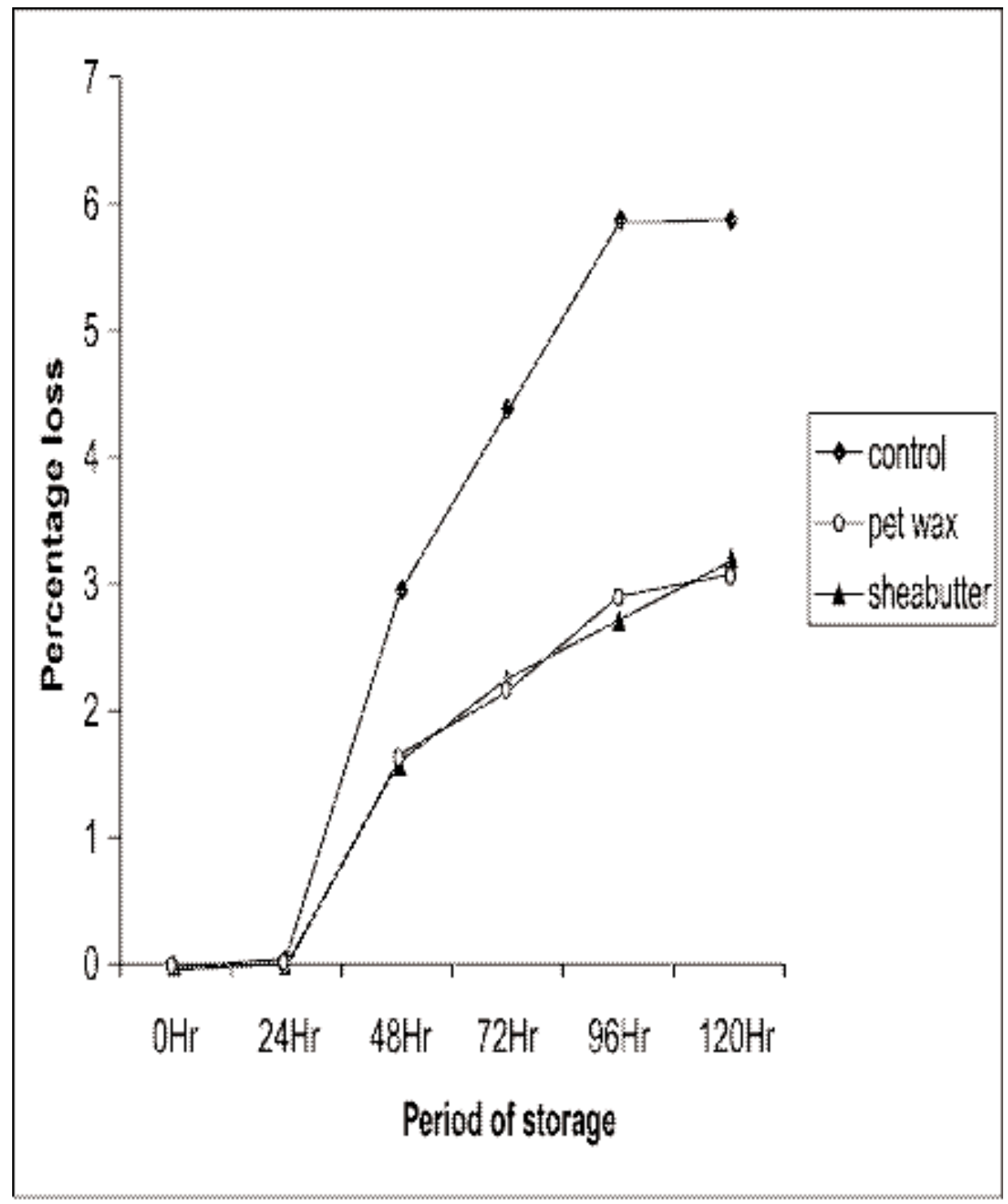

Fig. 1. Percentage weight toss of waxed and pnwaxed orange

and maintained an adequate external appearance. The vitamin $\mathrm{C}$ and the total phenol of the orange Citrus sinensis in storage are shown in Table I. Vitamin C is known to have many biological functions like ion collagen formation, absorption of inorganic iron, reduction of plasma cholesterol level, inhibition of nitrosamine formation, enhancement of the immune system and reaction with singlet oxygen and other free radicals (Lee and Kader 2000). The vitamin C content of orange was found to be $43.46 \mathrm{mg} / 100 \mathrm{~g}$. This value was low when compared to the value of vitamin $C$ reported for seed less guava (132mg/100g) and pawpaw (Carica papaya) (72.79mg/100g) (Adetuyi et al 2008b). Orange could be considered to have high vitamin $\mathrm{C}$ content compared to other fruits such as banana, dragon fruit and star fruit with vitamin C content of $4.9 \mathrm{mg} / 100 \mathrm{~g}, 8.0 \mathrm{mg} / 100 \mathrm{~g}$ and $5.2 \mathrm{mg} / 100 \mathrm{~g}$ respevtively (Lim et al 2006). During storage the vitamin $\mathrm{C}$ content of the orange reduced significantly $(\mathrm{P} \leq 0.05)$ in both waxed and unwaxed samples. (42.46 to $36.68 \mathrm{mg} / 100 \mathrm{~g})$. The loss in vitamin $\mathrm{C}$ during storage was in agreement with the report of Evensen (1983) and Albuquerque et al (2005) in the storage of musk melon. This result also agree with the observation that fruits and vegetable show a gradual decrease in vitamine $\mathrm{C}$ content as the temperature or time at storage time at storage increases (Adisa 1986; Biolaatto 2005). The observed effect ofstorage time on vitamin $\mathrm{C}$ degradation could be explained due to indirect degradation through polyphenol 


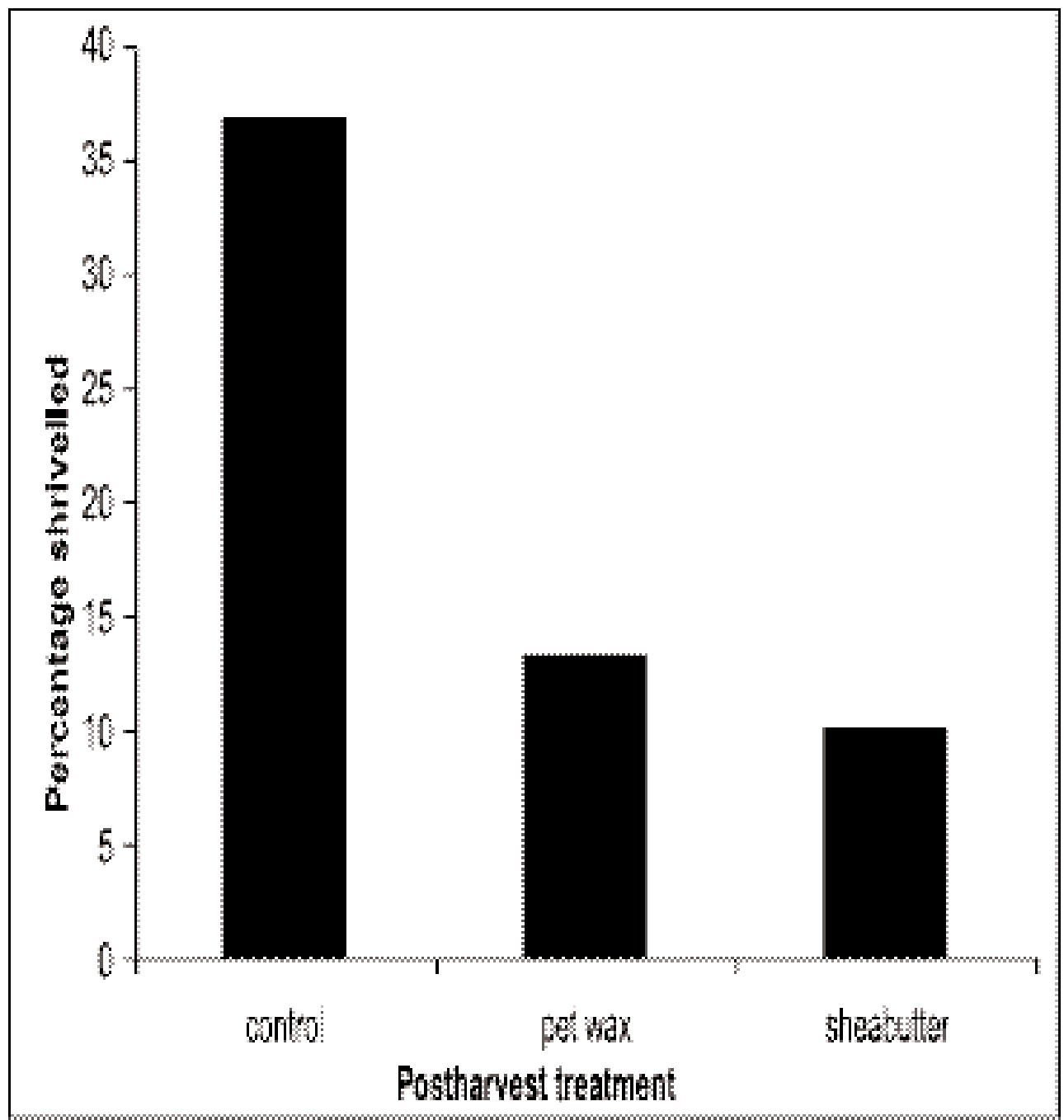

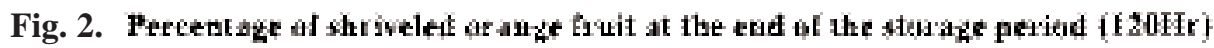

oxidase, cytochrone oxidase and peroxidase activity (Lee and Kader 2000). The orange waxed with shea butter had the highest content of vitamin $\mathrm{C}$ of $37.86 \mathrm{mg} / 100 \mathrm{~g}$. The reason why the untreated had the least vitamin $\mathrm{C}$ may be attributed to increase in the physiological activities in the stored orange which will enhance increase in the activities of the enzymes responsible for vitamin C degradation. Phenolics posses a wide spectrum of biochemical activities

Table I. Vitamin C and total phenol content of waxed and unwaxed orange in storage

\begin{tabular}{l|c|c|c|c|c|c|c}
\hline Quality & Trmt & $0 \mathrm{Hr}$ & $24 \mathrm{Hr}$ & $48 \mathrm{Hr}$ & $72 \mathrm{Hr}$ & $96 \mathrm{Hr}$ & $120 \mathrm{Hr}$ \\
\hline Vitamin C & Control & $43.46 \pm 0.1 \mathrm{a}$ & $42.61 \pm 0.02 \mathrm{~b}$ & $41.34 \pm 0.01 \mathrm{e}$ & $38.16 \pm 0.02 \mathrm{~g}$ & $37.17 \pm 0.01 \mathrm{i}$ & $36.68 \pm 0.021$ \\
$(\mathrm{mg} / 100 \mathrm{~g})$ & P wax & $43.46 \pm 0.1 \mathrm{a}$ & $42.02 \pm 0.01 \mathrm{c}$ & $41.28 \pm .02 \mathrm{e}$ & $38.79 \pm 0.01 \mathrm{f}$ & $37.10 \pm 0.01 \mathrm{k}$ & $37.86 \pm 0.01 \mathrm{k}$ \\
& S B wax & $43.46 \pm 0.1 \mathrm{a}$ & $42.82 \pm 0.01 \mathrm{~b}$ & $41.55 \pm 0.02 \mathrm{~d}$ & $39.64 \pm 0.01 \mathrm{f}$ & $38.95 \pm 0.01 \mathrm{~h}$ & $37.86 \pm 0.01 \mathrm{j}$ \\
\hline Total phenol & Control & $76.7 \pm 0.02 \mathrm{a}$ & $73.4 \pm 0.03 \mathrm{~b}$ & $65.8 \pm 0.03 \mathrm{c}$ & $55.9 \pm 0.03 \mathrm{~d}$ & $48.2+0.02 \mathrm{e}$ & $38.4 \pm 0.03 \mathrm{f}$ \\
$($ mgGAE/100g) & P wax & $76.7 \pm 0.02 \mathrm{a}$ & $71.6 \pm 0.02 \mathrm{~b}$ & $63.5 \pm 0.01 \mathrm{c}$ & $52.4 \pm 0.01 \mathrm{~d}$ & $44.8 \pm 0.01 \mathrm{e}$ & $35.7 \pm 0.02 \mathrm{f}$ \\
& S B wax & $76.7 \pm 0.02 \mathrm{a}$ & $72.6 \pm 0.01 \mathrm{~b}$ & $62.5 \pm 0.01 \mathrm{c}$ & $54.8 \pm 0.01 \mathrm{~d}$ & $46.7 \pm 0.02 \mathrm{e}$ & $36.2 \pm 0.01 \mathrm{f}$ \\
\hline
\end{tabular}

Value represent mean of triplicate

Values with the same letter along the same column are not significantly different $(\mathrm{p} \leq 0.05)$.

Trmt-treatment, P wax-petroleum wax, SB Wax-sheabutter wax 
Table II. Total sugar and glucose content of waxed and unwaxed orange in storage

\begin{tabular}{l|c|c|c|c|c|c|c}
\hline Quality & Trmt & $0 \mathrm{Hr}$ & $24 \mathrm{Hr}$ & $48 \mathrm{Hr}$ & $72 \mathrm{Hr}$ & $96 \mathrm{Hr}$ & $120 \mathrm{Hr}$ \\
\hline Total Sugar & Control & $\begin{array}{c}12.04 \pm 0.1 \\
2 \mathrm{a}\end{array}$ & $11.56 \pm 0.11 \mathrm{~b}$ & $10.61 \pm 0.12 \mathrm{c}$ & $9.66 \pm 0.14 \mathrm{~d}$ & $8.87 \pm 0.12 \mathrm{e}$ & $7.29 \pm 0.13 \mathrm{e}$ \\
$(\%)$ & P wax & $\begin{array}{c}12.04 \pm 0.1 \\
2 \mathrm{a}\end{array}$ & $9.50 \pm 0.13 \mathrm{~d}$ & $8.40 \pm 0.13 \mathrm{e}$ & $6.97 \pm 0.12 \mathrm{f}$ & $8.86 \pm 0.12 \mathrm{f}$ & $4.44 \pm 0.11 \mathrm{~h}$ \\
& S B wax & $\begin{array}{c}12.04 \pm 0.1 \\
2 \mathrm{a}\end{array}$ & $10.14 \pm 0.12 \mathrm{c}$ & $9.19 \pm 0.311 \mathrm{~d}$ & $7.92 \pm 0.13 \mathrm{e}$ & $6.66 \pm 0.11 \mathrm{f}$ & $5.39 \pm 0.12 \mathrm{~g}$ \\
Glucose & Control & $\begin{array}{c}0.087 \pm 0.0 \\
2 \mathrm{a} \\
(\%)\end{array}$ & $0.074 \pm 0.01 \mathrm{~b}$ & $0.062 \pm 0.01 \mathrm{~b}$ & $0.050 \pm 0.02 \mathrm{c}$ & $0.042 \pm 0.02 \mathrm{e}$ & $0.032 \pm 0.03 \mathrm{f}$ \\
& P wax & $\begin{array}{c}0.087 \pm 0.0 \\
2 \mathrm{a}\end{array}$ & $0.035 \pm 0.01 \mathrm{~d}$ & $0.027 \pm 0.02 \mathrm{f}$ & $0.018 \pm 0.02 \mathrm{~g}$ & $0.011 \pm 0.03 \mathrm{~g}$ & $0.005 \pm 0.02 \mathrm{~g}$ \\
& S B P wax & $0.087 \pm 0.0$ & $0.050 \pm 0.02 \mathrm{c}$ & $0.042 \pm 0.01 \mathrm{e}$ & $0.034 \pm 0.03 \mathrm{f}$ & $0.026 \pm 0.01 \mathrm{f}$ & $0.016 \pm 0.02 \mathrm{~g}$ \\
\hline
\end{tabular}

Value represent mean of triplicate

Values with the same letter along the same column are not significantly different $(\mathrm{p} \leq 0.05)$.

Trmt-treatment, P wax-petroleum wax, SB Wax-sheaabutter wax

such as antioxidant, antimutagenic anticarcinogenic as well as ability to modify the gene expression (Marinova et al 2005). The total phenol of orange was found to be $76.7 \mathrm{mg}$ GAE/100g (Table I). The value was in the range of total phenolic reported for orange, yellow apple and sweet cherry 75$78.8 \mathrm{mg}$ GAE/100g but lower to the value of star fruit seedless guava and blueberries 131-670.9mg GAE/100mg (Lim et al 2006 and Marinova et al 2005). The total phenol reduced in both waxed and unwaxed orange as the days of storage increased 76.7-35.7mgGAE/100g. This reduction in total phenol agreed with the findings of Ose et al (1997) and Lim et al (2006) in the study of stored water convolvulus leaves and guava. The loss in total phenol could be attributed to the action of polyphenol oxidase which causes the oxidation of the phenol to quinones (Kays 1991). Though there was reduction in the total phenol of the stored orange but there was no significant difference $(\mathrm{P}<0.05)$ in storage (12.04\% to $4.44 \%$ total sugar, $0.087 \%$ to $0.005 \%$ glucose). The reduction in sugar could be attributed to natural degradation (Adetuyi et al 2008c). In fact they become metabolically consumed in the respiratory chain due to phosphrylated equivalent synthesis (Albuquerque et al 2005). At the end of the storage period the sugar content of waxed orange was significantly $(\mathrm{P}<0.05)$ lower then the unwaxed orange ( $0.005 \%$ pertoleum wax, $0.016 \%$ shea butter). This could be attributed to the conversion of the sugar to ethanol which is primarily due to the inhibitory effect of the coating on gas exchange (Obeland et al 2008) of the orange.

\section{Conclusion}

This study has shown that the orange waxed are hygienically $(\mathrm{P}<0.05)$ better than the unwaxed orange in appearance and the percentage weight loss were also lower. The waxed oranges showed to contain high value of vitamin $\mathrm{C}$ when compared with unwaxe at every sampling point; however there was no significant difference in the total phenolic content of the waxed and unwaxed orange. Considering the apperance and weight of the orange, it is therefore concluded that orange transportation in Nigeria should be waxed with shea butter because it had better quality than unwaxed and petroleum waxed orange and also to prevent postharvest losses in these orange.

\section{References}

Adetuyi F. O, Osagie A. U and Adekunle A. T (2008a) Antioxidant degradation in six inigenous okra Abelmosclus esculentus (L) moench varieties during storage in Nigeria. J. Food Tech. 6(5) 227-230.

Adetuyi, F.O Akinadewo, L.T Omosuli S.V and Ajala, Lola (2008b) Antinutrient and antioxidant quality of waxed and unwaxed pawpaw carica papaya fruit stored at different temperature Afr. J. Biotech 7(16): 2920-2924

Adetuyi F. O., Ayileye T. A and Dada I. B. O (2008c) Comparative study of quality changes in sheabutter coated pawpaw carica papaya fruit during storage. Pakis. J. Nut 7(5): 658-62 
Adisa V. A (1986) The influence of moulds and some storage facotr on the ascorbic acid content o forange and pineapple fruits. Food Chemistry 22: 139-146.

Albuquerque B, Lidon F. C and Barreiro M. G (2005) A case study of tendral winter melons Cucumis melo L. post harest senescence. Gen Appl Plant Physiology 31:157-169

Arthey D. and Ashurt P. R (1996). Production and packaging of non-carbonated fruit juice and fruit beverage. Bla Acad Pro. (1) 152-167.

Aworh O. C., Nwankwo C. F. and Olorunda A. O (1991) Control of post harvest losses in citrus fruits under tropical conditions: effect of wax and fungicide. Tropical Science 31: 177-182.

Biolatto A., Sallito. V, Centet R. J. C and Pensel N. A (2005) Influence of different postharvest treatments on nutritional quality of grapefruts, Lebensm-Wiss. U-Technol 38: $131-134$.

Daramola A. M (1998) Postharvest handling of indigenous fruits and vegetables: Status, problem and prospect. Paper presented at the meeting of experts on indigenous crops and animal research and development, Nigeria.

Dhuique- Meyer, Caris- Veyrat C., Ollirault P., Curk F. and Amiot M. J. (2005) Varietals and interpecific inluence on micronutrient contents in citrus from mediterranem. J. Agric. Food Chem. 53:2140-2145.

Erinle I. D (1989). Present Status and prospect for increased production of tomato and peper in Northern Nigeria. Proc. Int. Symp. Integrated manage. Practices. AVRDC, Tainan, Taiwan.

Evensen K. B. (1983) Effects of maturities at harvest, storage temperature and cultivar on muskmelon quality. Hort. Sci, 18: 907-913.

Gomez K. P (2000) Effect of storage temperature and use of wax on the respiratory activities and internal composition of passion fruits passiflora edulis F. flavicarpa Degener c.v 'Maracuya'. Rev. Fac Agron (LUZ) 17: 1-9.

Harris J. R (1996) Ascorbic acid: Biochemistry and biomedical cell bioligy. In J.R Harris (Ed) subcellular biochemistry (P.25). New Youk Plenum press.

Idah P. A, Ajisegiri E. S. A. and Yisa M. G. (2007) Fruits and vegetables handling and transportation in Nigeria. AU.J.T 10(3): 175-183.

Kays S. J (1991) Post harvest physiology of perishable plant product Editor Kays S. J An Avi Book pp 532.
Lee S. K and Kader A. A (2000) Preharvest and postharvest factors influencing vitamin C content of horticultural crops. Postharvest biology and Technology 20(3): 207-220.

Levine M., Wang Y., Padayatti S. J and Morrow J. (2001) A new recommended dietary allowance of vitamin $\mathrm{C}$ for healthy young women proceeding of the National Academy of science USA, 98: 98429846.

Lim Y. Y, Lim T. T and Tee J. J (2006) Antioxidnat properties of Guava fruit; comparison with some local fruit. Suway Academic Journal (3) 9-20.

Marinova D., Ribarova F. and Atanassova M. (2005) Total phenolics and total flavonoids in Bulgarian fruits and vegetables. J. University Chemistry Technology \& Metallurgy 40(30): 225-260.

Matta F. B., Arjona H. E and Garner J. O (Jnr) and Silva J.L (2006). Studies on postharest quality of passion fruit. Bulleting 1153 of the division of agriculture, forestry and veterinary medicine of Mississippi state University.

Obeland D, Collins S, Sievert J. Fjeld K. Doctor J. and Arpaia M. L (2008) Comercial packing and storage of Naval oranges alter aroma volatile and reduces flavour quality. Postharvest biology ech. 47: 159-167.

Okhuoya J. A (1995) Controlling postharvest losses in tomatoes and pepper. J. Trop. Post harvest 2: 136-142.

Ose, K Chanchin K.U Jung- Nyung Lee, Gross K.C, Watada A.E and Seung Koo Lee (1997). Relationship between the occurence of chilling injury and the environmental gas concentration during storage of water convolvulus Impomoea aquatica F. Acta Hort No 483: 303-310.

Oyediran J.O (1988). Report of the nationally coordinated research project on fruit and vegetable in Nigeria. Proc. Nat. workshop on improved packaging and storage systems for fruits and vegetables in Nigeria, Ilorin. Nigeria.

Suntornsuk L, Kritsanapun W, Nilkamhank S and Paochom A (2002) Quantitation of Vitamin C content in herbal Juice using direct titration. Journal of pharmaceutical and Biochemical Analysis 28: 849-855.

Wills R. B. H, Wimalasiri P. and Greenfield H. (1984) Dehydroascobic acid levels in fresh fruit and vegetable in relation to total vitamin C activity. J. Agric Fd Chem. 329 (4): 836-838.

Received : April 01, 2009;

Accepted : September 16, 2009 